\title{
MIR193A wt Allele
}

National Cancer Institute

\section{Source}

National Cancer Institute. MIR193A wt Allele. NCI Thesaurus. Code C82147.

The human MIR193A wild-type allele is located in the vicinity of $17 q 11.2$ and is approximately 87 bases in length. This allele, which encodes MIR193A pre-miRNA, plays a role in the regulation of gene expression. Alteration in the expression of this gene is associated with development of oral squamous cell carcinoma. 